\title{
The Collision of Atomic and Flow Renewable Power in Decarbonization of Electricity Supply
}

\author{
Aviel Verbruggen, and Yuliya Yurchenko
}

\section{Abstract}

Transitions to sustainable, renewable energy supply are the major components of serious climate policy framed by the aims and constraints of sustainable development. The Paris Agreement does not provide the strategy, actions, instruments, or means to boost the transition processes in global North and South. The world's rich countries and people continue to exert rights to pollute the atmosphere with greenhouse gases. A spearhead climate policy can trigger fast elimination of energy-related carbon dioxide emissions, with full de-carbonization of the electricity supply as priority. Atomic power and flow renewable power (wind, solar, running water) are simply juxtaposed as the two major low-carbon supply options. In reality they are mutually exclusive in fully decarbonized power generation systems. They are hard to match technically while their major mutual impact is that they undermine the economic case for each other.

1 Aviel Verbruggen, University of Antwerp, Belgium, aviel.verbruggen@uantwerpen.be; Yuliya Yurchenko, University of Greenwich, United Kingdom, y.yurchenko@greenwich. ac.uk

(C) The Author(s) 2019

R. Haas et al. (Eds.), The Technological and Economic Future

of Nuclear Power, Energiepolitik und Klimaschutz. Energy Policy 


\section{Introduction}

COP21 was widely celebrated as a global achievement in tackling climate change certainly is a milestone in climate talks but does not bear enough thrust to spearhead enough action of enough urgency. It carries many endemic problems of previous international climate change agreements i.e., ambiguity of wording, lack of binding obligations, room for interpretation, etc. Too many concessions were made to turn it into text that all parties were ready to sign (Verbruggen, 2015). It came at a sacrifice of drafting the foundations of urgently needed frameworks for governing the global climate commons. The problem of differentiated responsibility for the current state and contamination of those very commons is not addressed in a meaningful way. By putting a price on GHG emissions, environmental destruction is traded, normalized and not addressed; inviting those who can afford i.e., rich countries whose industrialization destroyed the planet in the first place, to continue polluting.

A lot of energy intensive and contaminating production of industrialized countries has been allowed to move to newly industrialized and industrializing ones who are not economically strong to control and mitigate polluting or make polluters pay - something that too will not be solved without coordinated global action and a binding framework. Fast elimination of energy-related $\mathrm{CO}_{2}$ emission is needed. Two main low-carbon options are seen as a solution here: renewable power (solar, water, wind) and atomic. In this chapter we start from a brief comment on the COP21 Paris Agreement (section 2). In section 3 we focus on the question of rights to emit greenhouse gases and 'the polluter pays principle'. Section 4 presents the headlines of spearhead action in climate policy by fast elimination of energy-related $\mathrm{CO} 2$ emissions. It is followed by section 5 where we show that there are but few low-carbon energy supply options, with nuclear and flow renewable energy supply as the main contenders for providing electricity. Moreover, low-carbon is only one of energy supply options, which too need to be assessed for their overall sustainability performance as we discuss in section 6 . Nuclear power fails on crucial sustainability aspects and collides with the full expansion of flow renewable energy supply (wind, solar, running water) since, as we show in Section 7, the two low-carbon contenders undermine economic profitability of the other. The Conclusion summarizes our main arguments and recommendations. 


\section{Paris Agreement: winners and losers}

On December 12, 2015, French minister L. Fabius forged the general approval of the Paris Agreement after days and nights of tedious negotiations. Evaluations of the agreement range from 'historical success' to 'epic failure'. The 31 pages text of the Paris Decision \& Agreement is grey, vague, and silent about how UNFCCC will govern the global climate commons. It holds boundless opportunities for differentiated interpretation. PwC director J. Grant talked of "constructive ambiguity, or even woolly wording in some areas", and L. Fabius stated: "this allows all countries the ability to take the deal home and declare success". Ambiguity and woolly wording means that every party can read the text as their success and this speaks of a shaky contract. Without mastering COP's 24-year history and its jargon language, the Paris text is difficult to understand. For satisfying all COP delegations, the text is stripped of content, leaving voluntary efforts, voluntary contributions, and voluntary transfers as fillings for patchwork of voluntary projects. It is not clear who undertakes which projects, how and with whom, as the final decisions are under the discretion of "all Parties and non-Party stakeholders, including civil society, the private sector, financial institutions, cities and other subnational authorities, local communities and indigenous peoples". Does an agreement, allowing willing people to set up voluntary initiatives, generate sufficient thrust for drastic and urgent change? In our view it does not.

The unanimous adoption of the Paris text prompted praise, high expectations, and certainly relief for the club of veteran COP participants. The process was widely applauded by most media and societal groups: the many people and organizations concerned about derailing climate change, involved scientists, active governments, social organizations, banks, industrial companies, up to corporates with significant activities and assets related to fossil fuels and to atomic power.

Popular enthusiasm over marginal accord in the light of previous COP failures obscures the danger of agreements where interests of participants are too diverging, even opposite, and not reconcilable in the practical realization of the agreement. One tends to forget that the day-to-day economic priorities and limitation as well as ecological plans - or absence of such - in the participant countries will inevitably sour the optimism of the agreement. Industrialized countries' actions and intentions since the COP21 ovation do not appear assuring of their changing course. And these are the parties who should be global leaders of positive change due to their economic capacity and because of their role in destroying the environment in the first place. Instead, Norway, for example, plans exploitation of all its fossil fuel resources. The EU ETS permit prices per ton $\mathrm{CO}_{2}$ emitted hovered back to the $€ 5$ waiting dock, after a ripple beyond $€ 8$ during 2015 . France's investment in renewable 
energy fell from $€ 6.2$ billion in 2014 to $€ 2.9$ billion in 2015. After post-Chernobyl stalling, atomic power was brought back in as a solution to the inability to effectively reduce CO2 emissions (Mez, Schneider, and Thomas 2009) and is still on the table. The French nuclear conglomerates see the COP21 outcome as a window of opportunity for more atomic power projects. France is an important exporter of atomic power production with the state's heavy involvement in atomic producer ownership - AREVA and EDF are some $90 \%$ and $85 \%$ state owned and are world leaders in atomic exports (World Nuclear Association 2016). It is then not surprising that the French government promotes atomic energy as a "green option" at home and abroad (Ibid.). The option is, however, neither green, nor cheap in the short and long run alike as some $£ 18$ billion budgeted - with a very realistic prospect of adding $£ 2.7$ billion (EDF 2016) - Hinkley Point C project in the UK confirms (see also Schneider, Froggatt, and Thomas (2011) on high costs of atomic power). What the atomic option may do is pull urgently needed resources from being invested into truly sustainable, green projects.

COP21 did not establish the elementary conditions and instruments for starting an effective UNFCCC governance of the global commons atmosphere and climate (Verbruggen, 2015). Overall, major industrial, financial, and political interests have swindled good-meaning activists, environmental NGOs, and developing countries. Mass outsourcing of production to low-income countries and internationalization of production chains makes it harder to trace which country and whose companies pollute while it is the governments and end consumers who are being made to pay. IPCC, among other, document that 'a growing share of $\mathrm{CO}_{2}$ emissions from fossil fuel combustion in developing countries is released in the production of goods and services exported, notably from upper-middle-income countries to high-income countries' (IPCC 2014)

The economic and political ideologies and interests that created the energy and climate problems after World War II, continue to occupy the pole positions, now controlling the sort, price, and pace of the low-carbon energy transitions further jeopardizing possibilities for a progressive change.

\section{Rights to $\mathrm{CO}_{2}$ pollution or applying 'the Polluter Pays Principle'}

Addressing the annual 50Gt ton GHG emissions must be prioritised because climate change causes or aggravates the other daunting global problems (UNDP 2007). Governments and companies tend to convert the $+2^{\circ} \mathrm{Climit}$ into a spendable carbon 
emissions budget, considered and handled as 'rights to emit'. This practice rises the likelihood of transgressing the $+2{ }^{\circ} \mathrm{C}$ limit to near certainty and is geared towards appropriation by present rich countries and by carbon-intensive lifestyles, and is uncritically propagated by mainstream economists and media as a message that reads: 'by mitigating emissions, present generations deliver efforts and make expenses for the benefit of future generations'. This unwarranted rights position conflicts with a civilized status of environmental policy. Emitting $\mathrm{CO}_{2}$ in the atmosphere is an activity of dumping without hindsight or 'gaseous littering'. Industrialized societies acknowledge the 'Polluter Pays Principle' and polluters face two obligations: pollution must immediately stop and polluters must bear responsibility for the mess caused. Due to the atmosphere being the global commons, it is difficult to impose and enforce the actual implementation of the polluter pays principle. The way in which responsibilities are allocated in terms of 'right to pollute' and 'price of pollution' is ridden with problems. It is undisputable that 'both international and national decision making must aim to take account of income and wealth differentials and regional disparities within as well as between nations' (Newell et al 2015: 239). However, there is also the issue of difficulty to trace who pollutes what in internationalized production chains where countries, not companies, are held responsible for pollution that affects their geographic territory or the global atmospheric commons, while the profits from production more often than not escape those countries' controls.

\section{$4 \quad$ Spearheading climate policy by fast elimination of energy-related $\mathrm{CO}_{2}$-emissions}

Since the UN Framework Convention (1992), over the Kyoto Protocol (1997) and the Copenhagen Accord (2009), yearly global GHG emissions continued to grow, as did the annual use of commercial energy (IEA's yearly Outlook). About $4 / 5^{\text {th }}$ of GHG emissions are the result of present energy supply and use practices. In 2015 $\mathrm{CO}_{2}$ emissions growth stalled due to a global expansion of renewable energy supply. Presumably more than $4 / 5^{\text {th }}$ of the climate policy studies focus on energy-related $\mathrm{CO}_{2}$ emissions and their mitigation. Climate policy goes beyond the issue of energy (e.g., other GHG than fossil fuel related $\mathrm{CO}_{2}$, land-use, adaptation) but is also influenced by fossil fuels use (for example methane emissions, changing land-uses affected by low-priced supply of fossil fuels).

Ongoing climate policy is little effective partly because there are many goals on several aspects that are prioritized at the same time. Contrary to the widespread 
opinion that UNFCCC must mainstream and simultaneously solve multiple major problems of the world ${ }^{2}$, rational climate policy should detect spearhead issues functioning as locomotive in accelerating mitigation or adaptation. Strategic advance requires forcing change via a selected issue for breaking the locks on needed technological, industrial and societal transitions. Thorough transformation of energy supply and use is widely recognized as the predominant change to perform (IPCC 2012).

When COP Parties are serious about not crossing the $+2^{\circ} \mathrm{C}$ as a dangerous, they design and agree on Individual Parties' Emissions Contraction Scenarios (IPECS). For this, the focus is on $\mathrm{Cpp}=$ the average energy-related $\mathrm{CO}_{2}$ annual emissions per person in a nation. The Cpp indicator is a well-known Sustainable Development Indicator. Cpp is yearly assessed for all UN members and ranges from less than $100 \mathrm{~kg}$ in least developed countries to more than $20,000 \mathrm{~kg}$ in a few wealthy, oil intensive economies (IEA 2015).

Decomposing Cpp in three, still highly aggregated, factors provides insight and opens the entry to more detailed, hands-on information. The three indicators can be devolved further to reach detailed groups of actors emitting $\mathrm{CO}_{2}$ in specific conditions, offering neat hands-on policy targets ${ }^{3}$. Respective Cpp calculation is a multiplication of respectively wealth intensity, energy intensity of wealth, and $\mathrm{CO}_{2}$ intensity of energy use:

Figure 1 presents a stylized view of Cpp 'contraction \& convergence' scenarios for a few typical Parties with the agreed upon upper limit of Cpp, which contracts to a low point in 2050, e.g., a maximum of $500 \mathrm{~kg}$ Cpp. Every Party's scenario starts at its recently verified Cpp value. Every Party designs its Cpp path, respecting the constraint of staying below the commonly agreed upper limit. The actual Cpp contraction scenarios for sixteen, major $\mathrm{CO}_{2}$ emitting nations are documented in the Deep Decarbonization Pathways Project ${ }^{4} 2015$ report.

2 Paris Agreement p.1: "Parties should, when taking action to address climate change, respect, promote and consider their respective obligations on human rights, the right to health, the rights of indigenous peoples, local communities, migrants, children, persons with disabilities and people in vulnerable situations and the right to development, as well as gender equality, empowerment of women and intergenerational equity."

3 The decomposition can go on by splitting GDP in its major composing activities, by identifying actors related to the various activities, by specifying the types of energy used, etc. At UN level the higher aggregate suffices and further detailing is the task of the Parties to design the policies for controlling the values of the aggregate indicators. Agnolucci et al. (2009) and Verbruggen (2011) provide examples and suggestions of deeper decompositions.

4 An international consortium of research centers investigates 'deep decarbonization pathways' for a set of countries, together emitting three quarters of the global energy-related $\mathrm{CO}_{2}$ tonnage (http://deepdecarbonization.org). 


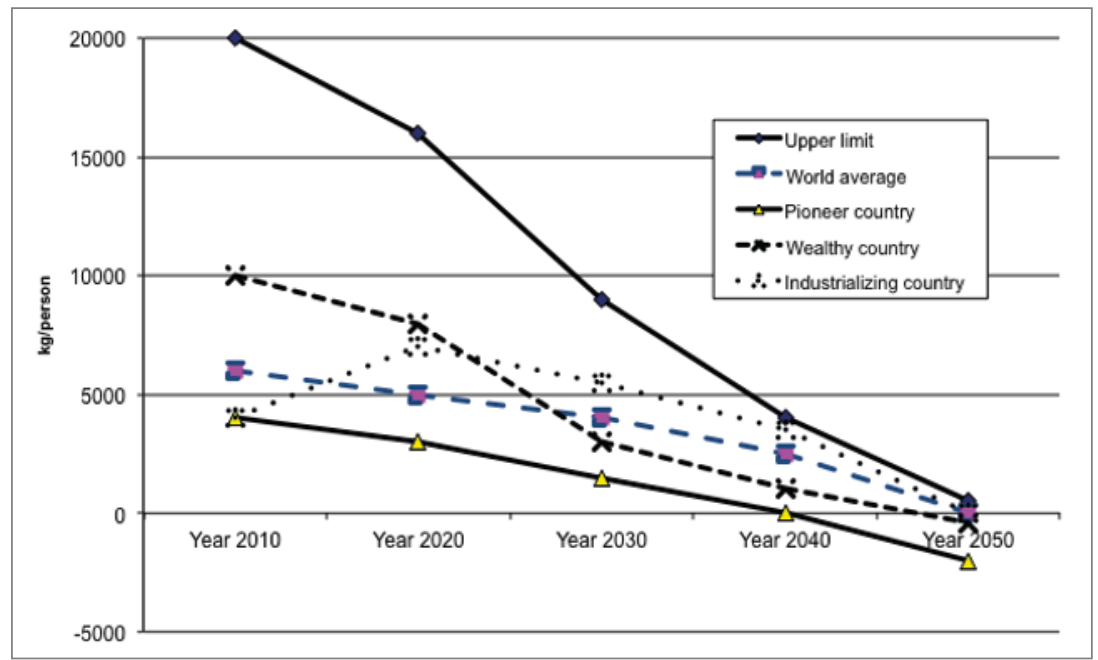

Fig. 1 Individual Parties' Emissions Contraction Scenarios materialize respect for the maximum $+2^{\circ} \mathrm{C}$ average temperature increase; stylized examples of representative cases, selected by the authors.

Decomposing energy-related $\mathrm{CO}_{2}$ emissions in constituent factors is a widespread practice (IEA 2015). IPCC reports take advantage of this decomposition for explaining the evolution of energy-related $\mathrm{CO}_{2}$ emissions (e.g. 2014 Assessment report, working group 3, chapter 6). The SE4All initiative of the General Assembly (UN 2011) wants to half the energy intensity (factor 2 of the equation) and double the use of renewable energy (factor 3 ) in developing countries. Therefore, it is amazing that official COP policy-making neglects the opportunities of decomposition for addressing the 'complex' and 'wicked' policy matters. Also MRV (Monitoring-Reporting-Verification) becomes really practical because numerical indicators are every year available for every factor:

1. The Budget Reform Index (BRI) for wealth intensity (GDP/person). The BRI should irrevocably increase year after year. Budget reform is financially promoting sustainable low-carbon activities and charging non-sustainable activities, leading to restructuration of the GDP. The monetary total of the GDP may increase or decrease by the restructuring. The discretionary power of how to practically organize the restructuring remains fully with the Parties. The 
BRI only gauges the overall net monetary pressure or thrust of policies for the promotion of sustainable low-carbon technologies and practices.

2. Energy intensity (energy/GDP) is a long-time documented indicator (Schipper et al. 1992, 2001; Geller and Attali 2006) and widely used by national and international energy administrations. Energy intensity combines the structure of an economy (how much of which activities take place) with energy efficiency (how much commercial energy is used by one unit of activity). The first factor is affected by budget reform (BRI); the second is mainly technological. Lowering energy intensity is generally high on the list of (proposed) energy and climate policies (IEA, EU, China). More effective progress is part of energy transitions. 3. Carbon intensity (emitted $\mathrm{CO}_{2}$ per unit of supplied energy) is the keystone for controlling $\mathrm{CO}_{2}$ emissions. Transitions to zero or almost zero carbon emitting energy uses by 2050 is the mission for all nations in the coming decades. Their transitions will be specific, due to differentiated endowment in resources, applied technologies, installed infrastructures, etc. However, all energy transitions are constrained by a small set of energy supply options [Figure 2].

The spearhead approach respects UNFCCC's 'common but differentiated responsibilities and respective capabilities' in emission reductions. 'Common responsibility' here is: all countries' Cpp stays below the upper limit scenario. 'Differentiated' here means: high value Cpp countries must contract first and at a fast rate ('deep cuts'); low value Cpp countries (mostly developing and least developed countries) can grow in Cpp value with the obligation to continue to respect the contracting upper limit values in future years.

\section{$5 \quad$ Few low-carbon energy supply options}

For performing activities, the right type and quantity of energy must be supplied at the right place and time. All energy supply are a combination of some energy source with particular technologies for exploration, generation, conversion, and transmission of energy to the end-users. In sequence of importance, available sources are: renewable flows and stocks in the natural environment, fossil fuel deposits in mines, wells, and shales, and uranium deposits (Figure 2$)^{5}$. The environment supplies for free many energy end-use services with little technology required for extraction or conversion, e.g., phenomena and processes such as

5 The overview does not include the manufacturing of synfuels. 
daylight, ambient heat, natural ventilation and drying. Natural processes concentrate diffuse renewable flows (photosynthesis, the water cycle). Over the last decade, the costs of man-made technologies harvesting renewable flows dropped significantly (IPCC 2012). Photovoltaics demonstrate strong performance on cost reduction in comparison with atomic (Haas 2012). Globally speaking, atomic has been showing a slowdown on new installations and decrease of capacity as an industry since 1988 (Schneider, M., Froggatt, A. and S. Thomas 2011). Technological capability announces further cost cuts, for example levelized $\mathrm{kWh}$ prices of conventional PV conversion to $€$ ct. 4 to 6 by 2025 and $€$ ct. 2 to 4 by 2050, although dependent on financial and regulatory conditions (Fraunhofer 2015). More innovative technologies can further reduce the costs. Costs distribution however needs to be further examined and reflected in any future policies as EU cross-country research suggests that it is still the households who bear most of the burden 'due to higher costs of direct energy efficiency expenditures in appliances, vehicles and insulation' (Haas et al. 2014).

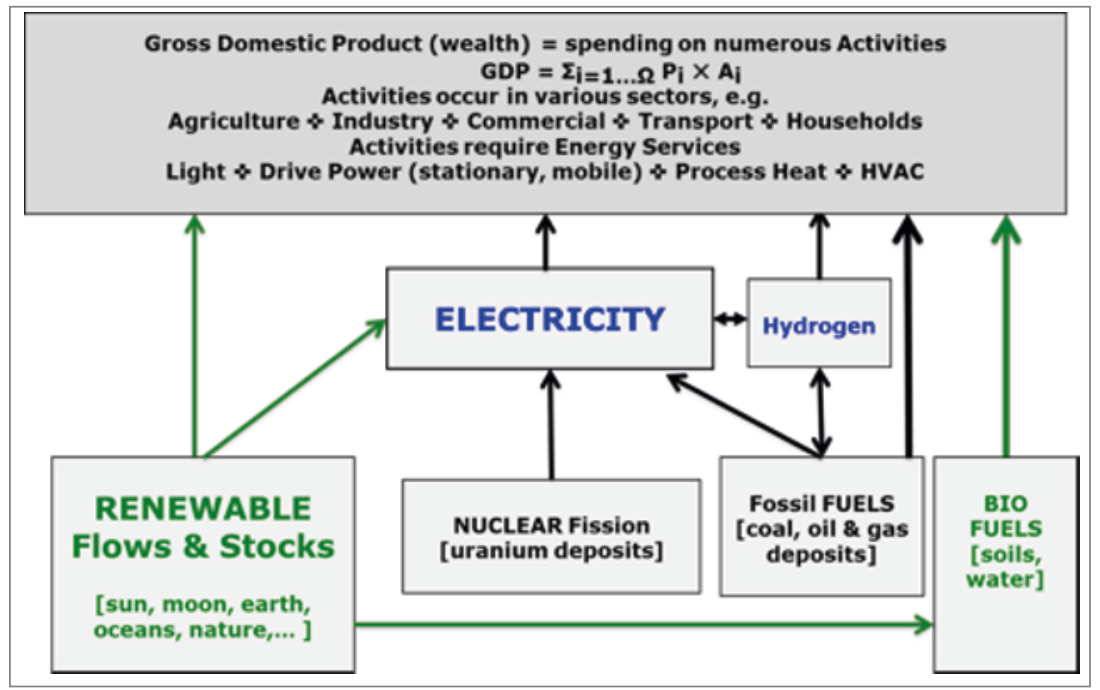

Fig. 2 Overview of energy supply categories, with energy sources in [.] Source: authors' graph.

Nuclear fuel is produced from refined and enriched uranium, dense deposits of which are limited (American Nuclear Society, 2001). Uranium shortage may be overcome 
by breakthroughs in breeder or fusion technology. Commercial new breeder and fusion plants are not expected before 2050, the year wherein carbon free electricity systems should be operational. Most essential is the high evidence that atomic fission power is not a sustainable power supply option (Verbruggen et al. 2014).

Fossil fuels cover a market share of above $85 \%$ of commercially traded energy supply (BP 2015). Their success is due to their versatility, density, (for all scales) divisibility, abundance, storability, and ability to perform on command. However, fossil fuel combustions cause various environmental damages and inevitably fetch $\mathrm{CO}_{2}$. In a low carbon future their use will be stifled (IEA 2014) but 'carbon lock-in' and related interests are exceptionally strong. A smooth phasing-out of fossil fuels is rather unlikely to happen (Verbruggen and Van de Graaf, 2013). Hydrogen is a carbon free fuel but is not naturally available on earth and difficult to manage safely. New industrial infrastructure may manufacture hydrogen from low carbon electricity but its deployment would be a costly, long-range undertaking. Other non-fossil solutions and options on storage and supply systems integration, some already available, need more investment for the successful and sustainable green energy transition. Electricity plays a central role in that transition as major renewable energy supply (PV, wind, water) and atomic energy is generating heat, mostly medium-pressure steam that is converted to electricity and delivers only power. The electricity sector transformation is the inevitable vanguard of the low-carbon energy transition.

\section{Climate change urges sustainable energy transitions}

The nuclear renaissance strategy is mostly argued in terms of necessity of atomic power in future low-carbon scenarios. Without public money continuing to subsidize new nuclear power projects, few projects will be started. Also with high subsidies, private investors in industrialised countries remain highly reluctant to invest in risk-prone nuclear projects. In order to obtain public support, the atomic hubris of the past century is shelved by a popular new slogan "Nuclear power is not the only solution, but there is no solution without". However, a majority of EU population prefer energy efficiency and renewable power (Eurobarometer 2015). Published statistics prove the fast diffusion of flow renewable power supply by technological innovation resulting in continuously declining generation costs. It has become the survival strategy of the atomic conglomerates to publicly propose co-habitance with renewable power while actually undermining its development because there is no compatibility for lots of renewable flow power and lots of atomic power in 
the same power system (Verbruggen, 2008). The exclusivity is technically due to physical attributes of electric currents and to the inflexibility of both atomic and flow renewable supply. The options perform differently on sustainable development criteria at the global societal level too.

Notwithstanding many regards towards sustainable development, IAEA skips the true sustainability assessment of atomic power (Verbruggen and Laes, 2015). The UK conservative government substituted the single low-carbon attribute for the spectrum of sustainability criteria covering Planet, People, Prosperity, Politics, and Risks as specific concerns. This reductionist interpretation equals the circumvention and obscuration of sustainable development also observable in the 2014-15 energy and climate policies of the EU (EC 2014a, EC 2015). Sustainability is, however, the primary attribute that future energy supply and use systems should have.

One aspect is the readiness of energy transition pathways for emulation by developing countries that is essential for global $\mathrm{CO}_{2}$ emissions reductions in the coming decades. Low-carbon energy systems composed of non-sustainable nuclear power and of centralized large-scale, capital-intensive renewable plants are not ready for emulation by the majority of developing countries. For the elimination of energy-related $\mathrm{CO}_{2}$ emissions, richer countries should develop and deploy renewable energy supply of the kind and size also applicable and affordable by developing countries. Indeed, there has already been progress made on the level of low-carbon energy transition assistance by World Bank and USAid. Power Africa (PA) is an initiative launched by the Obama administration in 2013 that 'works with African governments and private sector partners to remove barriers that impede sustainable energy development in sub-Saharan Africa and unlock the substantial wind, solar, hydropower, natural gas, biomass, and geothermal resources on the continent' (USAID 2013). The program's goal is stipulated as to 'increase electricity access by adding more than 30,000 megawatts of cleaner, more efficient electricity generation capacity and 60 million new home and business connections across sub-Saharan Africa' (USAid 2014). The Beyond the Grid sub-initiative aimed at expansion of rural electrification and providing 'access to small scale and off-grid technology' is also included in PA. One main recent project is the 'Lighting Africa' program - a 'joint initiative of IFC [International Finance Corporation] and the World Bank, [aimed to] help increase access to affordable, clean and safer lighting for more than 30 percent of Nigeria's population who live in rural areas, and have low incomes and no access to grid electricity' (IFC/WB 2015). The program focuses purely on private sector participation in electrification reform and expansion of the sector however the renewably sourced energy focus makes it more hopeful than the Power Africa initiatives. 
There are two big problems with the above initiatives. First is the involvement of private sector in delivery - usually associated with less reliability and higher costs (Yurchenko and Thomas 2015). The second is the inclusion of the fossil fuel natural gas as an energy source option, which is not a sustainable option. The two leave us skeptical of the potential final economic costs and effects of the program which seems to mimic typical issues of climate change politics governance discussed by Newell et al (2015) i.e., more of the same conventional approach.

A comprehensive sustainability assessment of nuclear fission power (Verbruggen et al., 2014) reveals that nuclear power fails on most sustainability criteria. The needs of countries with poor grid development and dispersed unsatisfied household electricity demand emphasize the shortfall of nuclear power as sustainability option.

\section{$7 \quad$ Flow renewable power and atomic power supplies are incompatible}

There is a growing literature on how integrated power generation systems may embed both flow renewable power (solar, wind, running water) and atomic power. At the outset, this literature adopts the present non-sustainable systems as the default position, with wind and solar power as disturbing newcomers. The incumbent position is: intermittent and stochastic renewable energy supplies disturb the reliable delivery of power; power on command is the reference. For a more effective and efficient transition the opposite viewpoint is needed: i.e., the future sustainability goal situation must be treated as a benchmark for assessing present states and required evolutions. Then the overarching guidance in the transition of the electricity sectors must be as follows: Intermittent and stochastic renewable energy deliver the most sustainable supply and merit priority over the non-sustainable supply; with respect for this sort of lexicographic priority, the supply of reliable power is organized, requiring extended load management capabilities, energy storage facilities, adapted transmission links to convey and match renewable power supply.

The atomic power and flow renewable supplies are mutually exclusive on five major directions of future power systems. First: atomic power is part and parcel of the expansive "business-as-usual" energy economy since the 1950s. Second, nuclear and renewable power need very different add-ons provided by fossil-fueled or bio-energy power plants, or by dam hydro power; for nuclear the add-on is large and expansive, for renewable power it is distributed, flexible and contracting over time. Third, power grids for spreading bulky nuclear outputs are of another constellation than the interconnection between millions of distributed power sources 
requires. Fourth, the risks and externalities of atomic power make this technology non-sustainable and therefore without a future. There is no safe or permanent way of disposing of nuclear waste - a problem that requires an international solution (Di Nucci and Losada 2015), effects of potential accidents are insurmountable, climate effects of ore mining are underestimated, emission of radioactive isotopes 'such as tritium or carbon 14 and the radioactive noble gas krypton $85^{\prime}$ are not discussed, etc. (Brunnengräber, et al., 2015; Smith, 2006; Mez, 2016); while efficiency/renewable power are still in their infancy particularly in terms of market shares. Fifth, the antagonistic competition for R\&D resources and for production capacities and capabilities (e.g., trained experts) will intensify. Nuclear power and renewable power have no common future in safeguarding "Our Common Future" (Verbruggen, 2008).

Fully sustainable renewable energy systems are not just technologically and economically feasible but also the cheapest and only sustainable option for the world's population. Like every successful transition, sustainable energy transitions need profound change in the minds, thinking, beliefs, preferences, etc. to adopt the novel paradigm, perspectives, technologies, and practices. Progressive thinking and actions are unlikely to be delivered by those with vested interests as we mentioned in the case of France, AREVA, and EDF. Although detailed technical analysis of dynamic power systems reveals the incompatibility of flow renewable and atomic

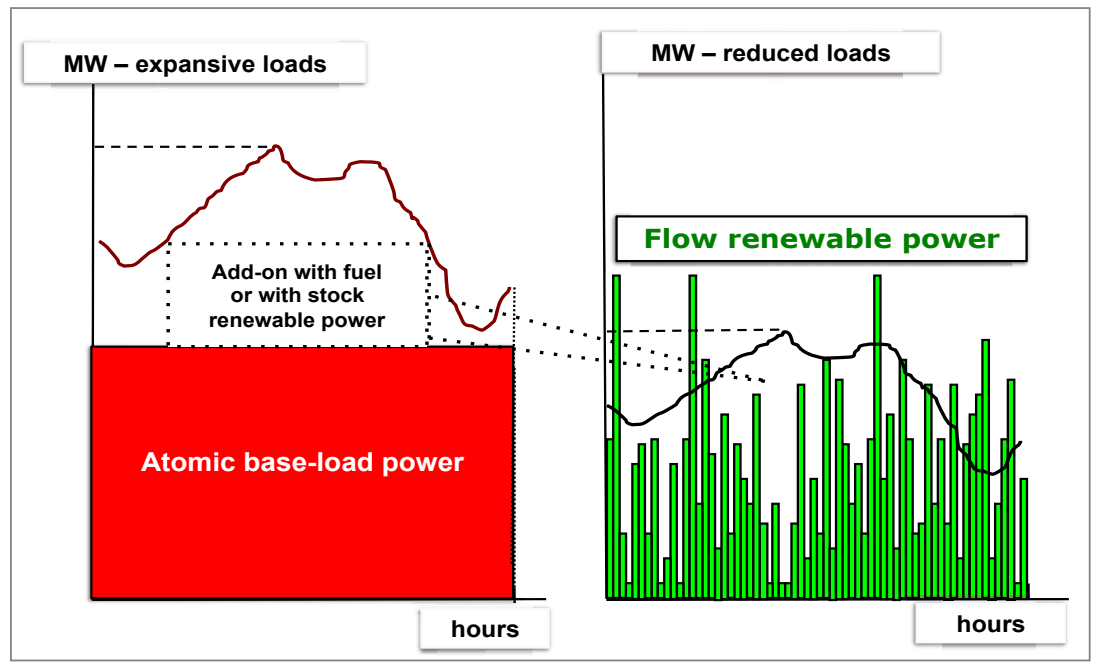

Fig. 3 Atomic versus flow renewable supply as separately serving electric loads Source: Verbruggen (2008) 
power supplies, the prevailing discourse repeats the mantra of a simple juxtaposition of both kinds of supplies (IPCC, 2014; UNFCCC, 2015; Verbruggen and Yurchenko, 2017).

This discourse can be continued when the contenders are embedded in separate power systems with ancillary supplies from fossil fuel based, bio-energy or hydropower dam electricity. However, when $100 \%$ carbon-free power in a particular power system is due, flow renewables and atomic power will collide. Both supplies are characterized by inflexibility, although of a different kind and for different reasons. There is a need for add-on current to fill the power loads from the supplied base onwards. Stapling supplies is the principle in merit order loading, not juxtaposing supplies, because electric power is an ephemeral phenomenon switching fifty times per second. Figure 3 shows the juxtaposition of atomic and flow renewable supplies in separately serving electric loads. Figure 4 illustrates that the two contenders will claim the same base-load area when operating in the same system.

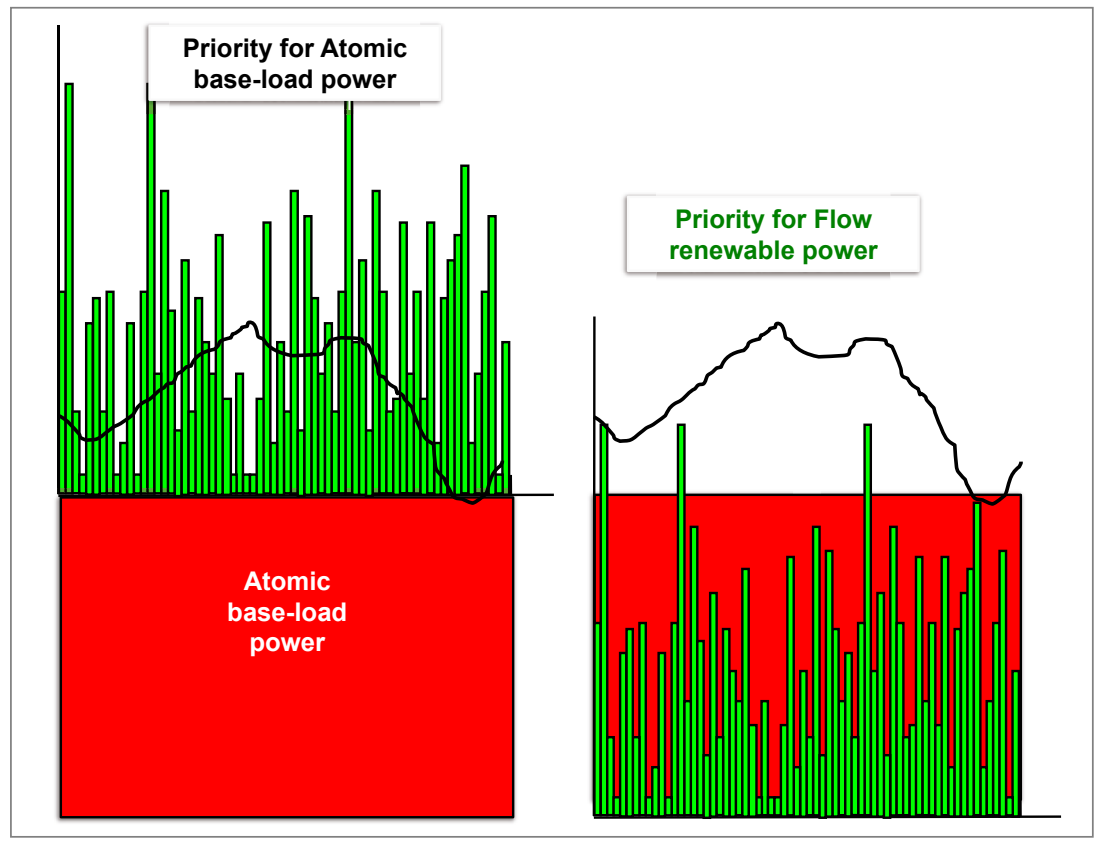

Fig. 4 Atomic and flow renewable supplies mutual impact when operational in the same power system.

Source: Compiled by the authors on the basis of Verbruggen $(2008,2016)$. 
As is shown in Figure 3, atomic power and flow renewable supplies serve separate power loads. They request add-on services from flexible power supply (fossil fuel or bio-energy based power or dam hydropower). Now more flexibility options are added like load management and storage in batteries (IEA, 2014). Supply from other areas in interconnected power systems is considered as a solution, although when the exchange becomes intense and frequent, the power systems become deeper interpenetrated. Figure 4 highlights how atomic and renewable supplies within one electric system ruin the business case for each other as their load factors are eroded when they cannot deliver the base loads. Researchers are looking into possibilities to enhance the load following capability of nuclear power plants, or to cut off sharp peak supply by wind or solar plants, or curtail their outputs for other reasons. Most studies focus on cases of limited annual supply by flow renewables (e.g., $20 \%$, or max.45\% of total annual power generated in the system) with a significant share coming from company owned larger scale plants (offshore wins parks; MW-scale PV fields; concentrated solar power). Our evaluation is that prosumers and cooperatives will become the predominant generators of flow renewable supply. The incompatibility between atomic and flow renewable power is stronger in terms of sustainability, economics, and involved agents than in technical operability.

\section{Conclusion}

The global climate policy process as deployed by the UNFCCC at the yearly COPs is slow and vague. The participants and most media acclaim COP21, but empirical and theoretical literature on the commons (Hardin, 1968; Ostrom, 1990) and problems of governance (Newell et al., 2015) predicts little positive results (Verbruggen 2015) without a comprehensive reconstruction of the governance regime altogether.

'Energy transition' is a term covering a spectrum of realities, from thorough and sustainable to superficial, deferring and non-sustainable lock-in. One slips in the latter without a clear definition, vision, mission or strategy of sustainable and thorough change. The incurred delays by the slips make the thorough path steeper, and the irreversibility of climate change more probable.

The sustainable renewable energy alternative as such is not costly when fully developed and deployed. Atomic power is and will be more expensive especially in the long run. Evidently, the transition process itself is challenging. Depending on the scores by progressive, viz. reactive strategies, forces, and public support, the transition difficulties and costs will be modest or high. In order to overcome 
the impasse, urgent transitions bring earlier depreciation of sunk investments. The latter are more significant when incumbent energy companies reacted little or very late to the 1992 Rio summit and ensuing conventions. For example, after 2000 , incumbent electricity companies have still built coal power plants in the Netherlands and in Germany (two countries of high exposure in energy transition literature and practice). This happened under the cover of the low $\mathrm{CO}_{2}$ emission permit prices of the failing EU ETS.

An assessment on nineteen sustainability criteria concluded that atomic fission power is not a sustainable option (Verbruggen et al., 2014). A full expansion of flow renewable and atomic power supplies too are mutually undermining in terms of reliability of supply and economic cost alike. A conclusion thus can be made that sustainable transition and sustainable power supply must focus and rely exclusively on renewable energy and renewable flow energy in particular as the main option to tackle climate change. The shift towards that option must happen quickly and will require coordinated efforts of countries globally. For this to be effective and making all parties responsible, a new, more binding, and clearly formulated framework of governance for the global environmental commons will need to replace the Paris Agreement and the business-as-usual functioning of the COPs.

Acronyms and Glossary: COP=Conference of Parties at the UNFCCC (yearly since 1995); $\mathrm{Cpp}=\mathrm{a}$ Party's average energy-related $\mathrm{CO}_{2}$ annual emissions per person; $\mathrm{EPR}=$ European Pressurized reactor; IAEA=International Atomic Energy Agency; INDC=Intended Nationally Decided Contributions (by Parties); IPCC=Intergovernmental Panel on Climate Change; $\mathrm{PV}=$ Photo-Voltaic; $\mathrm{RE}=$ Renewable Energy/Electricity; $\mathrm{SD}=$ Sustainable Development; UNFCCC=United Nations Framework Convention on Climate Change (1992).

This text uses mostly 'atomic' rather than 'nuclear' because splitting (or fusion) of atoms generates other atoms, as recognized in the 1950-60s. 


\section{References}

Agnolucci, P., Ekins, P., Iacopini, G., Anderson, K., Bows, A., Mander, S., Shackley, S., 2009. Different scenarios for achieving radical reduction in carbon emissions: A decomposition analysis. Ecological Economics 68: 1652-1666

Agora Energiewende, 2013. 12 Insights on Germany's Energiewende. http://www.agora-energiewende.de

American Nuclear Society, 2001. Generation IV Roadmap: Fuel Cycle Crosscut Group. Winter Meeting Reno http://gif.inel.gov/roadmap/pdfs/fuel_cycles.pdf

BP, 2015. Statistical Review of World Energy

Brunnengräber, A., Di Nucci, M.R., Isidoro Losada, A.M., Mez, L., Schreurs, M.A., Eds., 2015. Nuclear Waste Governance: An International Comparison. Wiesbaden: Springer.

Di Nucci, M. R. and Isidoro Losada, A. M., 2015. 'An Open Door for Spent Fuel and Radioactive Waste Export? The International and EU Framework', in: Brunnengräber, A., Di Nucci, M.R., Isidoro Losada, A.M., Mez, L., Schreurs, M.A., Eds., 2015. Nuclear Waste Governance: An International Comparison. Wiesbaden: Springer. Pp.79-97.

DDPP, 2015. Pathways to Deep Decarbonization. Executive Summary 2015 report. Deep Decarbonization Pathways Project. Sustainable Development Solutions Network (SDSN) and the Institute for Sustainable Development and International Relations (IDDRI). www.deepdecarbonization.org

EC, 2014a. A policy framework for climate and energy in the period from 2020 to 2030. European Commission COM (2014) 15 final.

EC, 2014b. Guidelines on State aid for environmental and energy 2014-2020. European Commission. Official Journal of EU 57 2014/C 200/01

EC, 2015. Energy Union Package. A Framework Strategy for a Resilient Energy Union with a Forward-Looking Climate Change Policy. European Commission COM(2015) 80 final.

EDF, 2016. 'Hinkley Point'. Available at: https://www.edfenergy.com/energy/nuclear-new-build-projects/hinkley-point-c/news-views/cost-clarification

Fraunhofer, 2015. ISE. Current and Future Cost of Photovoltaics

Geller, H., Attali, S., 2005. The experience with energy efficiency policies and programmes in IEA countries. Learning from the critics. IEA Information paper, Paris.

Haas, R., 2012. 'On the dynamics of Photovoltaics vs Nuclear power'. 2012 IEEE Third International Conference on Sustainable Energy Technologies (ICSET).

Haas, R., Liebmann, L., Lemprecht, M., Resch,G., Kahles, M. and F. Pause, 2014. 'Phase out of Nuclear Power in Europe - From Vision to Reality'. Global 2000 Report. Available at: https://www.global2000.at/sites/global/files/Nuclear_Phaseout_Study.pdf

Hardin, G., 1968. “The Tragedy of the Commons.” Science 162, no. 3859: 1243-48.

IEA, 2014. World Energy Outlook. International Energy Agency, Paris

IEA, 2015. CO2 emissions from fuel combustion. IEA Statistics 2015 edition.

International Finance Corporation/World Bank (10 March 2015) 'World Bank Group Launches the Lighting Africa Program for Nigeria'. Available at: http://ifcext.ifc.org/IFCExt/pressroom/IFCPressRoom.nsf/0/D3C00B7394A8D59E85257E0400319C58?OpenDocument

IPCC, 2012. Special Report on Renewable Energy Sources and Climate Change Mitigation. Intergovernmental Panel on Climate Change, Cambridge University Press; www.ipcc.ch IPCC, 2014. Intergovernmental Panel on Climate Change, Fifth Assessment Report, Working Group III Mitigation of Climate Change. www.ipcc.ch 
Mez, L., Schneider, M., and S. Thomas, Eds., 2009. International Perspectives on Energy Policy and the Role of Nuclear Power. Brentwood, UK.

Mez, L., 2016. 'Climate protection through nuclear power plants? Hardly.' In Bulletin of the Atomic Scientists. Available at: http://thebulletin.org/commentary/climate-protection-through-nuclear-power-plants-hardly9170.

Newell, P, Bulkeley,H., Turner, K., Shaw, Ch., Caney, S., Shove, E. and Pidgeon, N., 2015. 'Governance traps in climate change politics: re-framing the debate in terms of responsibilities and rights'. WIREs Climate Change, 6 (6). pp. 535-540.

Ostrom, Elinor, 1990. Governing the Commons: The Evolution of Institutions for Collective Action. Cambridge, UK: Cambridge University Press.

Schipper, L., Meyers, S., Howarth, R., Steiner, R., 1992. Energy Efficiency and Human Activity: Past Trends, Future Prospects. Cambridge University Press.

Schipper, L., Unander, F., Murtishaw, S., Ting, M., 2001. Indicators of energy use and carbon emissions: understanding the energy-economy link. Annual Review of Energy and Environment 26: 49-81

Smith, B., 2006. 'Insurmountable risks: the dangers of using nuclear power to combat global climate change'. A report of the Institute for Energy and Environmental Research. Available at: ieer.org/wp/wp-content/uploads/2006/05/InsurmountableRisks_2006.pdf.

Schneider, M., Froggatt, A. and S. Thomas 2011. '2010-2011 world nuclear industry status report' in Bulletin of the Atomic Scientists, July/August 2011 67: 60-77.

Töpfer, K., et al., 2011. Germany's Energy Turnaround: A collective effort for the future. Ethics Commission on a Safe Energy Supply, Berlin.

UK HM Government 2009. The UK Low Carbon Transition Plan.

UN 2011. Promotion of new and renewable sources of energy. Report of the Secretary-General. General Assembly Sixty-sixth session.

UNDP 2007. Human Development Report 2007/2008. Fighting Climate Change: Human solidarity in a divided world. Summary. United Nations Development Programme, 31p. http://hdr.undp.org/reports

USAid 2013. 'Power Africa Roadmap'. Available at: https://www.usaid.gov/powerafrica/ roadmap. 2014. 'Power Africa: About us'. Available at: https://www.usaid.gov/powerafrica/aboutus.

Verbruggen, A., 2008. Renewable and nuclear power: A common future? Energy Policy 36: 4036-4047

Verbruggen, A., 2009. Beyond Kyoto, plan B: A climate policy master plan based on transparent metrics. Ecological Economics 68: 2930-2937

Verbruggen, A., 2011. A Turbo Drive for the Global Reduction of Energy-Related CO2 Emissions. Sustainability 3, 632-648. www.mdpi.com/journal/sustainability

Verbruggen, A., Van de Graaf, T. (2013). Peak oil supply or oil not for sale? Futures 53: 74-85

Verbruggen, A., 2014. 'Could it be that stock-stakeholders rule transition arenas?' P.119-131 In Brunnengräber, A., Di Nucci, M.R., eds. Im Hürdenlauf zur Energiewende. Springer VS, Wiesbaden.

Verbruggen, A., Laes, E., 2015. Sustainability assessment of nuclear power: Discourse analysis of IAEA and IPCC frameworks. Environmental Science \& Policy 51: 170-180

Verbruggen, A., Di Nucci, M.R., Fischedick, M., Haas, R., Hvelplund, F., Lauber, V., Lorenzoni, A., Mez, L., Nilsson, L.J., del Rio Gonzalez, P. Schleich, J., Toke, D. 2015). Europe's electricity regime: restoration or thorough transition. International Journal of Sustainable Energy Planning and Management 5: 57-68 
Verbruggen, A., 2015. Self-governance in global climate policy: An essay. Essay EM-1. University of Antwerp. DOI: 10.13140/RG.2.1.1512.7128 (ResearchGate)

Verbruggen, A., 2016. Sustainability aspects of transitions to low-carbon electricity supplies. International Atomic Energy Agency, Technical Meeting. Amsterdam, June 21-23.

Verbruggen A., Y. Yurchenko, 2017. "Positioning Nuclear Power in the Low-Carbon Electricity Transition,” Sustainability. January 9/1 1-14.

World Nuclear Association, 2016. 'Nuclear Power in France'. Available at: http://www. world-nuclear.org/information-library/country-profiles/countries-a-f/france.aspx

Yurchenko, Y. and S. Thomas, 2015. 'EU Renewable Energy Policy: Successes, Challenges, and market reforms' with Stephen Thomas. PSIRU Report. Greenwich University: London

Open Access This chapter is licensed under the terms of the Creative Commons Attribution 4.0 International License (http://creativecommons.org/licenses/by/4.0/), which permits use, sharing, adaptation, distribution and reproduction in any medium or format, as long as you give appropriate credit to the original author(s) and the source, provide a link to the Creative Commons license and indicate if changes were made.

The images or other third party material in this chapter are included in the chapter's Creative Commons license, unless indicated otherwise in a credit line to the material. If material is not included in the chapter's Creative Commons license and your intended use is not permitted by statutory regulation or exceeds the permitted use, you will need to obtain permission directly from the copyright holder.

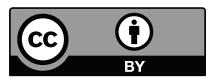

